Portland State University

PDXScholar

5-4-1995

\title{
The Effect of the Ideology of Motherhood on Women
}

Shari A. Burke

Portland State University

Follow this and additional works at: https://pdxscholar.library.pdx.edu/open_access_etds

Part of the Anthropology Commons, and the Women's Studies Commons Let us know how access to this document benefits you.

\section{Recommended Citation}

Burke, Shari A., "The Effect of the Ideology of Motherhood on Women" (1995). Dissertations and Theses. Paper 4894.

https://doi.org/10.15760/etd.6770

This Thesis is brought to you for free and open access. It has been accepted for inclusion in Dissertations and Theses by an authorized administrator of PDXScholar. Please contact us if we can make this document more accessible: pdxscholar@pdx.edu. 


\section{THESIS APPROVAL}

The abstract and thesis of Shari A. Burke for the Master of Arts in Anthropology were presented May 04, 1995, and accepted by the thesis committee and the department.

COMMITTEE APPROVALS:

Martha M. Balshem, Chair

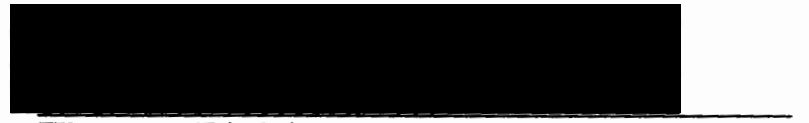

Thomas Biolsi

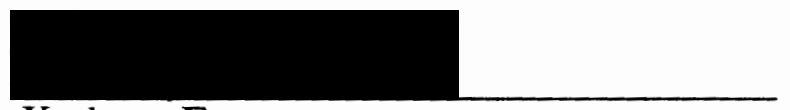

Kathryn Farr

Representative of Office of Graduate Studies

DEPARTMENTAL APPROVAL:

Marc R. Feldesman, Chair

Anthropology

ACCEPTED FOR PORTLAND STATE UNIVERSITY PY THE LIBRARY

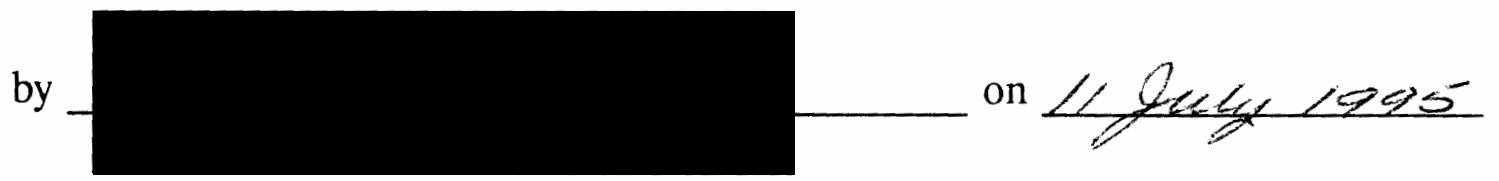




\begin{abstract}
An abstract of the thesis of Shari A. Burke for the Master of Arts in Anthropology presented May 4, 1995.
\end{abstract}

Title: The Effect of the Ideology of Motherhood on Women

The ideology of motherhood in the United States makes it seem as though motherhood is a natural role for women. The ideology holds mothers solely responsible for the well being of their children. Combined with the ideology of blaming the victim, the ideology of motherhood causes a great deal of guilt in women as mothers cannot possibly live up to the unrealistic expectations set up in the culture.

In this study, I have used two case studies to illustrate the impact of the ideology of motherhood on the lives of these particular women. Utilizing the theories of Michel Foucault and Antonio Gramsci, I will show how the ideology is constructed, internalized, and enforced in the United States. 


\title{
THE EFFECT OF THE IDEOLOGY OF MOTHERHOOD ON WOMEN
}

\author{
by \\ SHARI A. BURKE
}

A thesis submitted in partial fulfillment of the requirements for the degree of

\section{MASTER OF ARTS \\ in \\ ANTHROPOLOGY}

Portland State University

1995 


\section{ACKNOWLEDGEMENTS}

This work could not have been done without the help and support of the

members of the faculty of the Department of Anthropology. My experience here has been a positive one and I thank everyone for their support and encouragement.

Special thanks go to my graduate advisor, Martha Balshem, for never wavering in her belief that I would succeed. Her patience and support have been greatly appreciated and her ability to listen to what I wanted and to tell me how to go about getting it have helped me a great deal.

Special thanks also to Thomas Biolsi, my undergraduate advisor who also never stopped believing in me. It was in his Introduction to Sociocultural Anthropology class that I realized that I was an anthropologist. His unwavering support and encouragement have meant a great deal to me over the years.

I thank the graduate office representative, Kathryn Farr, for her very helpful comments on an earlier draft of this work.

My deep appreciation goes to the Anthropology Department's Office Coordinator and resident "Mom", Connie Cash, who took care of me when I needed it and who took care of problems as they came up. Her perky presence made coming to school every day a pleasurable experience -- Thanks Connie! For Ellen Franklin, my office mate over the past year and my new friend 
whom I feel as though I've known for years -- thank you for listening to me whine and for making me laugh. I'm glad we got to spend the year together.

A huge "thank you" goes to the families (especially the mothers) who let me come into their lives and who shared their stories with me. I could not have done this work without their help.

Finally, I thank Bill and Heather from the bottom of my heart for all of their love and support, without which I would never be here. Through all of the crazy times during this educational process, they were there for me, always believing that I would succeed. I hope that I can be as loving and supportive as Bill takes his turn.

This work is dedicated to Bill and Heather. 


\section{TABLE OF CONTENTS}

PAGE

$\begin{array}{ll}\text { ACKNOWLEDGEMENTS } & \text { ii }\end{array}$

CHAPTER

I INTRODUCTION 1

II THE SOCIAL CONSTRUCTION OF MOTHERHOOD IN 11 THE U.S.

III THE CASE STUDIES 22

I. THE SULLIVANS

II. THE PETERS $\quad 29$

IV CONCLUSIONS 38

CASE STUDIES: DESCRIPTIVE SUMMARY

REFERENCES 


\section{CHAPTER I}

\section{INTRODUCTION}

Ideology has been described by Barbara Katz Rothman as "the way in which a group looks at the world, the way it organizes its thinking about the world" (1994:139). Ideology leads us to believe that our way of looking at the world is "natural" or "just the way things are." In the case of motherhood in the United States, a powerful ideology is at work. This ideology has a profound effect on women in this culture, whether they are mothers or not. Although there are different perspectives regarding how tightly ideology fits us and whether it is possible to totally resist ideologies, I argue that escape from certain ideologies is very difficult. In fact, in the case of the ideology of motherhood, I argue that every mother is affected to the ideology, albeit to varying degrees.

The ideology of motherhood in the United States makes it seem as if motherhood is a natural role for women--all women want to be mothers and all women will be good at it (Glenn 1994; Berry 1993; Radl 1987; Faraganis 1986). Motherhood is seen as beautiful and as central to the well-being and happiness of every woman in this culture (Berry 1993; Schwartz 1993; Radl 1987). Women who are not mothers have to deal with the guilt society puts on them to have children. They are made to feel guilty and selfish for not having or wanting to have children (Schwartz 1993; Radl 1987). For women who do make the choice 
to have children, guilt comes from the feeling that they are not doing their job well enough and their children will suffer--fear that is reinforced by the cultural expectations of what a mother is.

The ideology tells us that mothers are (or should be) constantly nurturing, willing to sacrifice their own needs at all times to meet the needs of their children (Glenn 1994; Forcey 1994). They are expected to do this gladly and without complaint. Of course, ideas about what children need are socially constructed as well, and this changes over time. It follows, then, that what constitutes a "good mother" has changed over time as well however, the ideology remains in place. Because the role of mother is seen as one that comes naturally to women and since this role is defined for women by the patriarchal culture in which we live, women are "locked into biological reproduction" and are denied "identities and selfhood outside mothering" (Glenn 1994).

The ideology helps to maintain the division of labor both inside and outside the home. Inside the home, women are expected to do the household labor--it is seen as an extension of their mothering role. Whether they work in the paid labor force or not, women do most of the household labor (Hochschild, 1989), labor that benefits everyone in the household. Outside the home, women predominate in jobs that extend their caring role into the paid labor force. Most nurses, elementary school teachers, and secretaries are women. These jobs are typically low paying and have little prestige attached to them (Berry 1993; MacKinnon 1989). In recent years, ideas like the "Mommy Track" have surfaced. 
The idea here is that there should be a separate career path for women who need or want to work, but do not want to devote all of their time and energy to their careers while (the implication is) neglecting their children. Note that it is not called a "Daddy Track" or a "Parent Track"--it is a "Mommy Track."

The ideology is guilt inducing for women and is part of what anthropologist Maxine Margolis calls (after William Ryan) "the ideology of blaming the victim" (1984:236). This ideology is called (by Margolis \& Ryan) a "system-maintaining ideology." These types of ideologies have "a role in explaining or rationalizing the culture's existing structure" (Margolis 1984:236). According to Maxine Margolis:

The ideology's primary function is to obscure the victimizing effects of social forces. .. Instead of analyzing the inequalities caused by social conditions, the ideology focuses on the group or individual that is being victimized. The victims then, are blamed for their misfortune. . . change, says the ideology, involves changing the victims rather than the circumstances under which they live (1984:236-237).

One aspect of this victim blaming ideology is the concept of "mother blame." In this view, any problems faced by the child are seen as the result of a lack in the mother herself, or in the way she mothers (Code 1991; Margolis 1984), because women are held responsible for the well-being of their children.

The ideology of blaming the victim is a very important aspect of the ideology of motherhood and serves to perpetuate guilt women feel at not living up to the ideal. Betsy Wearing says:

One of the functions of the ideology which has already been evident in the internalization of guilt by these mothers, appears to be to individualize motherhood and its responsibilities, placing all the blame or praise on individual mothers while obscuring the 
institution of motherhood which serves society's interests and ignores some of the needs of mothers and their children (1984:67).

In mothers, society has a scapegoat on which to place the blame when things go wrong.

Women are caught in a bind. They are the people who are given the responsibility for the well-being of their children. If they do not work in the wage labor force in order to "be there" for their children, they are seen as overinvolved, smothering, and not competent to hold a "real job" (Margolis 1984). If they work in the wage labor force, they are seen as selfish and neglectful (Margolis 1984). In any case, by placing the blame for children's problems on the mother, society does not have to shoulder any of the responsibility. If everything can be laid at the feet of one person, there is no pressing need to do anything about poverty, bad schools, and day care. If a child gets into trouble, it is because their mother was at work and she is a "latch-key kid" or because their mother was at home so the child has been "smothered" or "overprotected" (Coontz 1992; Margolis 1984).

The ideology is perpetuated in many ways. The media produce and reproduce the ideology (Glenn 1994; Walters 1992). Television portrays women in ideal terms or as pathological. New mothers are often portrayed as ambivalent about going back to work when their maternity leave is over. There is a vague idea in these shows that one cannot be a really good mother and go off to work, too. In the end however, mom usually goes back to work having found a good babysitter for the child. Of course, she also worries that the baby will grow more 
attached to the babysitter than to her. Rarely do you see a mother portrayed in a positive light who is happy to go back to work and comfortable with her decision to do so. Also left out of the picture are those women who do not have a choice. If they feel any ambivalence, they must simply deal with it because not going back to work is just not an option for them.

Another way the ideology perpetrates itself is through mother-daughter relationships and through woman to woman relationships. Some women are highly conscious of the fact that they are setting an example for their daughters of what a mother is or should be. They do not want their daughters to be caught in the same bind they themselves are in. However, "such awareness does not make the search for and development of alternatives much easier" (Gordon 1990:62). Daughters observe their mothers and base their expectations of what motherhood is all about partly on the example set by their mothers. This helps the ideology to perpetuate itself.

Women also fall into the trap of holding other women up to the ideal and blaming them when they fail to live up to the "standard." As Maxine Margolis puts it:

Women not only participate in the ideology, they sometimes internalize it, blaming themselves and other women for a host of problems. In fact, the very persistence of victims blaming is partly a result of the implicit and explicit participation of its targets, strong evidence of the ideology's effectiveness in rationalizing subordination (1984:262).

We can see a vicious cycle at work here. Women as mothers are idealized in this culture, but then the very ideology is used to oppress them. Motherhood is 
used to define what a woman is, thus limiting opportunities for women outside motherhood. Women can be aware of the ideology at work, but alternatives are difficult to come up with. Further:

Even those who are highly critical of the way motherhood has been distorted by patriarchal, capitalist ideology, tend to romanticize the experience of motherhood, using the same language of naturalism that they deplore as sexist when used by anti-feminists. Moreover, given the hegemony of sexist ideology, motherhood is often the only basis for women to claim status and privilege (Glenn 1994:23).

It is understandable that women would be reluctant to change the only institution in this culture where they are given status and are the central actors (at least in theory).

It may appear on the surface that in the United States, the ideology of motherhood can be empowering to women because it gives them a certain amount of power. If one digs deeper, however, one can see that this is not the case. The ideology places incredible pressure on women to live up to impossible expectations. Women feel conflicted about their responsibilities to their children, their spouse or significant other, their employers, and themselves. The ideology forces women to juggle all the different parts of their lives and they can only hope that all of the balls stay in the air--if a mother drops a ball, she is led to believe that serious consequences will follow. Of course, this need to keep up the juggling act has serious consequences for her own life. Since no one is perfect and there are other pressures on kids, every mother will "drop the ball" where her children are concerned at some time. Often this will be due to things beyond her control, but, as we have seen, blame will be attributed to her, leaving feelings of 
guilt, unhappiness, and extreme stress that may manifest itself in physical ways. Many social scientists, including some anthropologists have looked at the construction of motherhood. This work has, interestingly, been done mainly in Western, industrialized societies like Australia (Wearing 1984); Canada (Rossiter 1988); Britain (Llewelyn \& Osborne 1990); and the United States (Glenn 1994; Margolis 1984). Although feminist anthropologists in the 1970's began to focus on women's roles in production and subsistence cross-culturally, there has been little work done on the construction of motherhood outside the West, although there has always been a focus on kinship in anthropology. The little work that has been done on the construction of motherhood cross-culturally (eg Scheper-Hughes 1994, Wolf 1994), shows that motherhood is constructed differently in different cultures.

The goal of this particular study is to see how the ideology of motherhood and the ideology of victim blaming come together to affect the lives of women. In the following sections, I will lay out the methodology that was used to conduct this study. I will give a historical overview of motherhood in the United States in order to show how the ideology has changed and how the current ideology came to be. I will then present two case studies done with mothers in order to illustrate the effects of the ideology on their everyday lives. A major theoretical issue I will explore is how tight a hold the ideology of motherhood has on these two mothers. Finally, I will analyze this qualitative data using concepts put forward by Michel Foucault (disciplinary practices) and Antonio Gramsci (hegemony). Finally, I will 
discuss the role of the anthropologist in looking at this issue.

\section{METHODOLOGY}

This qualitative study was conducted to explore ways in which the ideology

of motherhood, as currently constructed in the United States, effects the everyday lives of mothers. To do this, I chose two families to observe. Both families are two parent, white, suburban families with two daughters, the kind of family held up as the ideal.

Because of the hidden nature of this phenomenon, I expected that formal interviews and questionnaires would not be useful. One needs to observe family members interacting with each other and to talk to the women informally about their experiences of motherhood; it was for this reason that I chose the case study methodology. Yin argues that "the case study allows an investigation to retain the holistic and meaningful characteristics of real life events. . " (1984:14). This type of research method is commonly utilized by anthropologists to allow them to observe everyday events in people's lives.

Because ideology causes us to see motherhood as a natural role for women and constructs motherhood in ways that are often hidden, I expected that formal interviews would be less than productive, so I scheduled a great deal of informal time with each family. This expectation was borne out as the informal interviews and the observations were far more illuminating than the formal interviews however, the case study method (which calls for the use of all these methodologies) is appropriate in this case because the ideology at work is subtle 
and often (in fact, most of the time) mothers are not aware of its influence. If something goes wrong they are far more likely to blame themselves rather than the unrealistic expectations placed on them by the culture.

In terms of the informal interviews, I believe my own status as a mother helped the women to feel that they could speak to me more freely because they assumed that I would understand some of the things they were talking about. They probably felt more comfortable talking to "one of their own" than they would have to a man or a woman who was not a mother.

In order to see how the families interacted, I conducted participantobservation with both families and informal interviews with both mothers. In addition, I conducted a more formal interview with one of the mothers. I knew both mothers before the study began.

The first family is middle/upper middle class (based on income level and the social circles they move in). Although I realize the term "middle-class" is problematic, I base this classification on the definition put forward by Rayna Rapp:

Households among the middle-class are obviously based on a stable resource base that allows for some amount of luxury and discretionary spending. When exceptional economic resources are called for, nonfamilial institutions usually are available in the form of better medical coverage, expense accounts, pension plans, credit at banks, and so on. Such households may maintain their economic stability at the cost of geographical instability; male career choices may move households around like pieces on a chessboard (1992:64).

They live in a predominately white, suburban neighborhood and own their own home, which is fairly large. The mother in this family is, at the time of this study, 
a stay-at-home mother. She does attend college, but schedules classes around the schedules of her daughters. I spent approximately 15 hours observing this family in the summer of 1994 with the longest single stretch of time being six hours. I have conducted approximately 20 hours of informal interviews with this mother over the course of eight months. I have also conducted a more formal interview that lasted approximately one hour. I spent a total of 36 hours with this mother.

The second family is working class, and they often struggle to stay there. They live in a more racially diverse neighborhood than the first family. They rent half of a duplex and they have never owned their own home, nor are they likely to do so in the near future. Their living space is quite small. This mother has worked in the wage labor force for the past four years; before that, she was a stay-at-home mother for 13 years.

In the fall of 1994, I was able to stay with this family for five days. I spent approximately 35 hours in direct contact with the mother, observing, doing informal interviews or both. In the past four months, I have also done three informal interviews with this mother over the telephone, each lasting one to one and one half hours. I spent approximately 39 hours with this mother. This case study was far more observation-based than the first.

This meets the criteria stated by Yin (1984) and Balshem (personal communication) for spending 20 hours in contact with each family. 


\section{CHAPTER II}

\section{THE SOCIAL CONSTRUCTION OF MOTHERHOOD IN THE U.S.}

This study focuses on the dominant Euro-American culture, thus the discussion of the social construction of motherhood that follows is based on the ideals from this segment of the culture. I chose this segment of the population to investigate because it is the culture of which I am a part and I felt I would learn about my own experiences of motherhood by studying how motherhood is experienced by other women in situations similar to my own. In addition, this is the segment of the population held up as the "ideal", even though no one can completely live up to the ideology. Further, this is a segment of the population often overlooked by anthropologist in favor of "the other", less dominant segments of the population in the United States.

European and Euro-American ideas about what makes a "good mother" and what mothers should do to raise their children "properly" have changed over time. Even childhood was not always viewed in the same way it is today. The idea of a prolonged childhood during which the child is dependent on her parents for survival is a relatively recent invention. In this section, I will outline the history of the ideology of motherhood. This will serve to show that what we believe about motherhood today is arbitrary and culturally constructed, and it will locate the current ideology in the present day. 
The following history is reviewed by Berry (1993), Coontz (1992), Skolnick (1991), Mintz \& Kellogg (1988), and Margolis (1984). The reader is referred to these authors for a more extensive description of the history of family life in the United States.

In the eighteenth century, there was little separation between home and workplace. The work of survival was done at home. This was an agrarian based economy and everyone contributed. Thus, child-rearing was not an activity that was separate from public life. Children were simply taught survival skills in the course of everyday life. Child-rearing was not done exclusively by women. Men also worked at home, so they were involved at least to the same extent women were in child-rearing. There were also often other adults in the home. Elderly relatives, boarders, and apprentices often lived with families. Parents usually had large numbers of children as well, so there would have been older children in the home taking care of some of the needs of the younger children. According to Berry (1993), Mintz and Kellogg (1988) and Margolis (1984), the mother-child bond was not prominent in these families. There were many people who disciplined, supported, and cared for children in the household.

Childhood during this time was also different from the way in which we view childhood today. Parents were not given a great deal of advice on how to raise children as they are today. Sermons of the day instructed parents to discipline their children and to teach them Christian values (Margolis 1984). Children were usually expected to work around the household at an early age and 
by 6 or 7 years of age, some children were sent out to work as apprentices for others (Margolis 1984).

Infant mortality was very high during this period--Maxine Margolis (1984) has stated that in the colonies during this time, the infant mortality rate was 10$30 \%$. Sermons of the time gave parents the message that the death of a child was "Gods will" and parents should be stoic about it (Margolis 1984).

By the mid 1700 's, we can see the beginnings of what came to be known as "the cult of motherhood." It was a time of industrialization and the economy was no longer based almost exclusively on agriculture. Work was no longer a part of domestic life. There came to be a separation between the workplace and the home. this meant great changes in family life in general.

First of all, men began to work in settings outside the home, thus they were no longer present in the home to help raise the children. Another issue was that skilled workers and artisans stopped taking in apprentices. This meant that not only were there fewer "outsiders" living in the household, but it also meant that children were not being sent out to work for others. Children now stayed in their own homes for longer periods of time (Mintz \& Kellogg 1988; Margolis 1984).

The birth rate began to fall in the mid 1700's as well. According to Maxine Margolis (1984), in the town of Gloucester, Massachusetts, for example, women who married before 1740 averaged 6.7 children, those who married after 1740 averaged 4.6 children. Clearly, households began to have a different structure than they had previously. 
The sexual division of labor underwent great change at this time. When households were producing most of what they needed, there was work that women usually did and work that men usually did, but there was much overlap between "women's work" and "men's work." As industry grew, a particular division of labor began to take shape. Women were given responsibility for domestic work while men worked outside. Women had less contact with the world outside their homes.

The concept of what "home" was supposed to be also began to change. Previously we have seen that home was a place where the work of survival was done. Now, home began to be seen as a refuge from the outside world. By the mid 1800's, as Maxine Margolis (1984) puts it:

The removal of production from the home to the factory led to the breakdown of the once close relationship between the household and the business of society. For the first time 'life', that is, the home, was divided from 'work'. Not only had the two spheres become separate, they were now seen as incompatible; the home was a retreat from the competitive world of commerce and industry, a place of warmth and respite where moral values prevailed. The business of the world no longer took place at home (29).

According to Coontz (1992), Thorne (1992) and Mintz \& Kellogg (1988), the family was now seen as a private place where companionship and mutual affection were emphasized. Happiness was to be found at home and not in the competitive world of work.

As the process of industrialization continued, the ideology of childhood began to change. Children came to be seen as individuals who needed "special nurturing" in order to reach their full potential (Margolis, 1984). Because men no 
longer spent as much time in the home as they had previously, the duty of caring for children fell on the shoulders of women. Mary Frances Berry states that:

Only women, under the new dispensation, could be a source of moral values and a counterforce to the commercialism and self interest that accompanied male economic and political activities (1993:51).

Not only did mothers have more responsibility than they had previously had, but this responsibility lasted longer. Children began to stay at home until late in adolescence. The birth rate declined throughout the nineteenth century--"from 7.04 children per white woman in 1800 to 3.56 in 1900" (Margolis 1984:30). Mary Frances Berry (1993) and Maxine Margolis (1984) argue that because women were having fewer children, they had more time to devote to each one. After 1830 , there was a great increase in advice manuals directed at mothers, but this cannot be explained by the falling birth rate alone.

Margolis argues that part of the reason motherhood changed at this time was that there was a need for future professionals to be reared in the "proper" way in order to fill all of "the management positions being created by the industrializing process. What better and cheaper way to accomplish this than by urging middle class women to devote many years and large quantities of their (unpaid) time and energy to nurturing the future captains of business and industry" (1984:31)? Of course, mothers and no one else were responsible for how their children turned out. By the mid-1800's, experts on child-rearing were saying, in essence, that "... good mothers produced good boys and bad mothers produced bad boys" (Margolis 1984:37). 
From approximately 1870-1890, motherhood became "professionalized" (Berry 1993). Child rearing was "scientized" and can be seen as being "part of a general movement that viewed science as the key to solving social problems" (Margolis 1984:39). Children began to be studied scientifically and eventually organizations such as the National Congress of Mothers, the Child Study Association, and other less formal clubs devoted to child study were formed.

Psychology was a new discipline at this time and many new "experts" on childhood were trained at this time. These "experts" would be the people who would tell women what was best for their children. Mothers were to do what these "experts" advocated (Berry 1993).

This move toward scientizing childhood did not mean that the more emotional aspects of motherhood were no longer seen as important. Maxine Margolis quotes Edward Bok, the first editor of "Ladies Home Journal" (which began publication in 1889) as saying that "a mother was still the 'fountainhead' of the home and her 'civilizing force' was undiminished because 'man in the outer world is her emissary, carrying out the ideas she early implants in his mind" (1984:40). Mothers were not to work outside the home, according to the experts, because this would be damaging to their children (Berry 1993).

In the early 1900's, the role of the "scientific experts" began to increase and by about 1920, the idea of "the dangerous mother" came into being (Margolis 1984). While the idea that "bad" mothers raised "bad" children had existed for some time, it was thought that "bad" mothers were uncommon. As the raising of 
children came under the scrutiny of the experts, it was believed that ignorance on the part of mothers of "the principles of human development" caused them to raise "weak and warped offspring" (Margolis 1984:44). In fact, Mary Frances Berry argues that some "went so far as to opine that children might be better off trained in controlled environments rather than in the family home" (1993:90). The solution was a "highly scheduled, almost military approach to child raising" advocated by the experts (Margolis 1984:44). This held sway through the mid 1940's with some experts arguing for this kind of upbringing so that the child, once grown, would be able to "make it in the tough competitive world of industrial capitalism" (Margolis 1984:52). Margolis argues that this "scheduling movement" should be placed within the larger context of the 'scientific management' movement, an early twentieth century movement that sought to apply the methods of science to the control of labor in capitalistic enterprises. (1984:56). The mother was expected to "schedule and regulate the hours of sleeping, feeding, and elimination" in preparation for the world of work where "management was supposed to set the pace, time, and scope of work" (Margolis 1984:56).

After World War II, the economy was dependent on greater consumption, so ideals of discipline and self-control were pushed aside for more self-indulgence and individuality. This could be seen in the realm of child rearing advice given by experts who now advocated permissiveness. In this way of thinking the mother would abandon the idea of scheduling and listen to the baby's needs. For 
example, mothers were advised to feed the baby when the baby indicated she was hungry, not on a certain schedule. The experts of the time told women to be stimulating and affectionate toward their children and to trust their own instincts up to a point, but to also consult with doctors to get the proper advice. The mother was to be constantly available to her child and mothering was considered to be "fun" (Ehrenreich \& English 1978). In this view, mothers would be fulfilled because their "maternal instinct" made mothering "natural" (Coontz 1992; Margolis 1984).

While this push to make mothers stay in the home and devote themselves to child rearing was going on, it is thought that mothers were coming back into the home after working in the wage labor force during the war. Berry (1993), Coontz (1992), and Margolis (1984) argue that in fact, during this time, many women continued to work at least part time in order to afford some of the new consumer goods that were becoming available, such as major appliances or second cars or did volunteer work. In fact Berry states that "even in the 1950's the proportion of women with small children who sought paid unemployment increased by one-third" (1993:117). In 1940, 21.6 percent of wives had wageearning jobs; by 1960, this had increased to 30.5 percent (Berry 1993). Stephanie Coontz points out that "... by 1952 there were two million more wives at work than at the peak of wartime production" (1992:31). These jobs had low pay and low prestige however, so women still defined themselves in terms of their mothering role (Coontz 1992). 
This was contrasted by an opposing view that was also popular at this time-mothers as overprotective and pathological. Mothers would fall into this category if they were too "domineering" or too "submissive." These ideas had always been around, but there was an increase of them during the post-war years. Berry (1993), Margolis (1984), and Ehrenreich \& English (1978), argue that this was an attempt by some experts to explain "casualties" in the psychiatric wards of hospitals during the war. They argue further that these ideas can be explained by the fact that mothers and children were isolated in their homes as middle-class people moved to suburbia in large numbers.

The 1960's can be seen as a transition period for mothers. The idea that women did not have to devote all of their time to child-rearing was once again becoming popular. Fathers were beginning to come back into the parenting picture as their importance was recognized once again. By the 1970's, in fact, it was being argued by the experts that "mothering" could be done just as well by fathers as by mothers. The important thing was that the child have a consistent "mother-figure" to rely on.

Also during this time, mothers were having the blame for "bad kids" taken off of their shoulders. Experts began to criticize the ideal that said that healthy children should be raised by one person in relative isolation from the community (Berry 1993; Margolis 1984; Ehrenreich \& English 1978). Mothers were told by experts that it was fine if they got a job outside the home--their children would not suffer (Margolis 1984). In fact, it might be good for the child to have a 
mother who works outside the home because this could help the child become more independent. It was also thought that children who had mothers in the paid labor force would grow up to have fewer sex role stereotypes.

In the 1970's, mothers themselves began to write about their experiences as mothers (Rich 1976; Radl 1987 [1973]). While these books, in general, acknowledged that motherhood could be a source of satisfaction and great joy, they also acknowledged that it could be a source of pain and frustration at times.

It would seem that we are now living in a time when mothers are once again being expected to bear total responsibility for their children (Berry 1993; Schwartz 1993). Women are once again blamed if things "go wrong" with their children (Berry 1993; Schwartz 1993). Media reports of women leaving the workforce to stay home with their children are common (Coontz 1992). There is much media attention focused on "latch-key children" and all of the consequences of this phenomenon--obesity in children, "couch-potato" children, violence among children, just to name a few. By placing the responsibility for this on mothers, we let society off the hook for not having adequate day care or after school facilities for children. Conservative politicians lament the passing of the "traditional family" and argue that the family is in crisis. However, as Judith Stacey points out:

Rarely do the anxious outcries over the destructive effects on families of working mothers, high divorce rates, institutionalized child care, or sexual liberalization scrutinize the family behaviors of men. Anguished voices, emanating from all bands on the political spectrum, lament state and market interventions that are weakening the family'. But whose family bonds are fraying? Women have 
amply demonstrated our continuing commitment to sustaining kin ties. If there is a family crisis, it is a male family crisis (1990:26869).

Currently, women are being given mixed signals. On one hand, women are expected to be working in the paid labor force if they wish to do so. Women are also expected to have children and stay at home with them if they wish to do so (Berry 1993; Schwartz 1993). As we have seen, each decision carries with it negative connotations. Women who have children and paying jobs are seen as neglectful while women who are stay-at-home mothers are seen as incompetent. As always, the person who will suffer from the mother's decision is the child according to the ideology. The ideology of motherhood holds children as hostages and forces women to try to live up to expectations that are so unrealistic, they will always fail to some degree to live up to these expectations. As Betsy Wearing (1984) has pointed out, one result of this is the internalization of feelings of guilt on the part of mothers.

In this section, I have tried to show how ideology of motherhood has changed over time in the United States. Because we can trace the history of this ideology, we can see that ideas about mothering and motherhood as we know them are not natural. They are cultural constructs that are specific to a particular time and place. Whatever the current ideology, there is a profound effect on women's lives. I will now describe the two families I observed in order to illustrate how the ideology of motherhood impacts the lives of these two particular mothers. 


\section{CHAPTER III}

\section{THE CASE STUDIES}

\section{THE SULLIVANS}

The Sullivan family is a white, middle-class family that lives in a large (approximately 3,000 square foot) house in a suburban neighborhood. The predominately white, suburban neighborhood the family lives in was chosen in part because the parents felt that the school system was a good one. There are four people in the Sullivan family: Sandra (the mother), Brian (the father), Shawna (15), and Denise (13). Lydia, Sandra's mother, lives nearby in a house just a few minutes away. She has been ill and had to move to be close to Sandra so Sandra could care for her.

Brian has a job in which he has had to travel a great deal over the years, so often he has not been home. The primary unit in the home over the years has generally been Sandra and her daughters, although Rrian would try to be involved when he was home.

For most of her married life, Sandra has been a housewife. She has seen her primary responsibility as raising her children. This has been especially important to her since Brian was away so much. Because of the financial security Brian's job gives them, Sandra has been able to be a "stay-at-home mom." This 
was her choice and she does not regret it, although she acknowledges that it has been very difficult. Currently, Sandra attends a university in the area, and she is starting to think about what she wants to do with her life once her children are grown.

Shawna, the eldest daughter, is a quiet young woman. She likes to read and do figure skating. Shawna has had difficulty in school because she learns differently than most children. She has been diagnosed with Attention Deficit Disorder (ADD) and has also been classified as gifted. Sandra has had to spend a great deal of time over the years helping Shawna with homework and staying in close contact with teachers and school administrators. Because of Shawna's particular difficulties, according to Sandra, "The kid has had two to three hours of homework a night since she's been in second grade." Denise is more boisterous than her sister. She does well in school. She is involved in sports. Usually, the responsibility for driving her to and from practices falls on Sandra's shoulders.

There is a fairly stereotypical division of labor in the home. Brian is responsible for the financial support of the family, Sandra is responsible for the home and the children. Car repairs and yard work, typically considered "male" tasks, are done by people hired for this purpose, so Brian does not have to do these tasks.

I will now describe a day in the life of the Sullivan home as I observed it. I met Sandra downtown one summer day, and we rode over to her home together. We chatted on the way over. 
Sandra was very happy because Shawna had been getting herself up at 5:30 am so she could be ready to go to school by 7:00. This is important to Sandra because it is her responsibility to drop off Shawna on her way to school. If Shawna is late, so is Sandra.

Once we get to the home, Shawna is home from school and we all sit in the living room and talk. The discussion centered around Shawna's school experience. School was going well for her and she was proud of how well she was doing.

She had recently gotten braces, and there was a piece of wire sticking out, jabbing her in the cheek. She had to go to the orthodontist to get this fixed. Sandra called the office to try to arrange an office visit to get this fixed. The secretary tells her they can go in right away and we go.

As we sit in the waiting room, the discussion turns to a homework assignment that Shawna has to do but is not happy about. She has to make a mask based on a myth that is not Greek or Roman in origin. She cannot think of what to do, so she asks her mother for help. She goes to have the wire fixed and we leave. On the ride home, the discussion about the mask continues, with Sandra trying to come up with some ideas to help her.

When we arrive back at the house, Denise is home. Sandra, Shawna, and I go back into the living room and Denise is told to go get ready for soccer practice. Someone will be picking her up to bring her to practice. Sandra will have to pick-up Denise and two of her friends and bring them home. 
It is decided that dinner that night will consist of food from Taco Bell. Shawna groans and says she is sick of Taco Bell. Sandra does not feel like cooking, however, so Taco Bell it is.

Denise's ride arrives and at the same time, Brian comes home from work. He comes in and sits down. He has had a difficult day. He is in the midst of a professional decision and it is causing him a great deal of stress.

At this point, I leave the room to use the phone. When I come back, Brian is demanding that some kind of limit be put on soda consumption in the household. He goes on for a few minutes. Sandra nods and says okay. Shawna rolls her eyes. In what seems like an attempt to diffuse the situation, Sandra tells Shawna to go do her homework and says that she and I will go to the store and to Taco Bell. Sandra asks Brian if he wants anything at the grocery store. He says he wants Diet Pepsi (along with a few other things). Shawna makes a comment about how odd this request is considering his speech about soda consumption just a few minutes earlier. Sandra tells him that if she buys soda for him, she will buy some for the girls, too.

We go to the store and Sandra buys soda for everyone. We go to Taco Bell and get dinner. We go back to the house and eat--Denise's dinner is put away for her to heat up later. After dinner, Brian puts his dishes in the sink and puts away some leftover food. Sandra tells him he has done enough and he can go. Brian goes to his home office to do some work and is not seen again this particular evening. 
We chat at the table for awhile and then Sandra realizes that it is time to go pick up Denise. We get into the car and drive across town. About a half-hour later, we arrive at the field where soccer practice is taking place. Practice is running late and so we wait. Finally, practice is over. The kids collect their gear and we all head toward the car. By this time, it is getting dark outside (it is after 8pm). Two kids are dropped off at their homes and Sandra reminds them as they leave to be ready for the next day's practice as she will be picking them up.

Finally, we get home and Denise heats up her dinner and prepares to go do homework. Shawna comes upstairs needing help with her math homework. Sandra tells her that she should ask her father because he's better at math, but he is busy so Sandra tries to help her. By this time, it is $9 \mathrm{pm}$ and I leave to go home.

I have had many hours of conversation with Sandra since that day, both by telephone and in person in places other than her home. Based on these conversations, it seems thai this is a non-typical day in her life. It was not nearly as busy as most days are.

To begin with, it was late summer and although her kids were in school, classes had not yet started for Sandra. She also did not have to drive Shawna to and from figure skating lessons (which often happens) and she only had to drive Denise home from soccer practice (she often has to drive both ways).

Sandra's life is extremely busy. She has the responsibility not only for her own work at school, but also for helping her kids when they need help. She is 
responsible for getting them back and forth to soccer, basketball, and skating practice, as well as to doctor's and orthodontist's appointments. If there is a problem at school with one of her child's teachers, it is her responsibility to deal with it. There are days when Sandra gets up in the middle of the night to do her own homework, gets Shawna to school, goes to school herself, and puts in a full day there, goes home and drives kids to practice and the doctor, sees that everyone gets dinner, helps with homework and falls exhausted into bed so she can get up the next morning and do it all again.

Sandra has been taking classes at the university for a number of years. She wants to go on to graduate school eventually and is sometimes frustrated because she has had to take so long to finish. When she first started going to school, she had to go part-time and could not take classes after a certain time because she had to be home for her children. When her mother became ill, she had to take an entire academic year off in order to care for her. Sandra is very aware that she has put her own wishes aside in order to fulfill what she sees as her responsibility to her family.

Sandra told me that she stayed home with her children because she felt it was what was best for them, but it was a sacrifice on her part. In fact, she says "I would never have made the sacrifices I've made if I didn't have children." Sandra feels that part of the reason she feels so strongly about this is because her own childhood was unhappy. She says that "at seventeen I was doing things adults didn't want to deal with." She says this made her strong, but also adds to the 
burden she feels she carries about being a good mother. She is so determined to not do the same things to her children that were done to her--she feels tremendous pressure.

Sandra discusses the fact that although she understands intellectually the concept of the ideology of motherhood and is often aware of it at work in her own life, when asked if this knowledge and awareness eases the guilt she feels, she quickly answers, "Absolutely not."

Sandra says that she "has been a feminist since I was 16 ", and in fact she never thought she would marry and have children. When she and Brian decided to start a family, they also decided to marry. As Sandra puts it, "I got beaten down by life." Her children are not very far apart in age. Sandra was isolated because the family moved a lot for Brian's career. She became depressed. Still, she says she sacrificed her own well-being for that of her children.

Sandra anticipates these sacrifices continuing. She wonders whether she will end up going away for a $\mathrm{Ph} . \mathrm{D}$. program because something inside her tells her that it is her "responsibility to have a home base for my kids to come back to."

Sandra has begun to make changes in her life. She has now scheduled an occasional late afternoon or night class, leaving Brian responsible for some of the carpool duties and meetings with teachers. She is trying to meet her own needs. She says "Even when I am the most stressed out about school, it's nothing compared to the stress I felt when I was home with my kids." Sandra credits her own inner strength with helping her to struggle against the ideology. "I have to do 
this or die", she says.

\section{THE PETERS}

The Peters family is a white, working class family who live in a major urban area in the Western United States. They rent one half of a duplex in a neighborhood comprised of small duplex houses. Although they technically live within the city limits, this neighborhood appears to be more like a suburb.

There are four people in this family: Joan, the mother; Bob, the father; Nancy (16) the eldest daughter; and Michelle (11) the youngest daughter. In addition to the people, there is a large dog, an Amazon parrot, a cockatiel, and a cat. All of these people and animals inhabit a very small space. Their living space consists of a living room, a small kitchen/dining area, two bedrooms, and a bathroom. There is a tiny patch of grass in the front and a little patio in the back. The family members are on top of one another all the time.

In the fall of 1994, I stayed with this family for five days. Judging from telephone conversations I have had with Joan since then, it seems that what I observed was pretty typical in terms of how life is for Joan and the rest of the family.

I arrived at about 10:30 on a Sunday morning. The sun was shining and it was pleasant outside, however, the forecast was for $100^{\circ}$ heat later that day. Joan was going to take advantage of the weather and hang a load of clothes outside to dry, so when I got there, she was already up and dressed and she was doing laundry. Bob was still in his robe and the kids were still asleep. Joan put her 
laundry in the washing machine, which is located in the garage, and we go into the living room to talk. Bob takes a shower, gets dressed, and joins us. He immediately turns on the television to watch football. He begins to make racist jokes and comments. No one laughs. Joan seems a bit nervous whenever he does this, but she doesn't ask him to stop. One of the family jokes seems to be that the dog barks very loudly and gets very excited when he sees people with "dark skin." Joan comments that this is the perfect dog for Bob.

I ask to use the bathroom and I am shown the way. A gate is across the entrance into the bedroom/bathroom area because the cat is afraid of the dog, so they must keep the two animals separated. I climb over the gate and find the bathroom. I also find a stack of "Playboy" magazines next to the toilet. I wonder what it must be like for Joan, Nancy, and Michelle to have to deal with that every time they use their own bathroom.

I return to the living room and the conversation continues. It does not take Bob long to begin to make his wishes known. He begins to complain to Joan that he is hungry and wants to know what she will make for lunch and when she will make it. Joan t:1!s him that she will go to the store in a little while, then she'll come and make lunch. This does not satisfy Bob who continually interrupts the conversation with comments like "I guess we're not going to get any lunch today, honey." This continues for about an hour and a half. No one is eager to go out in the heat, but Bob is becoming unbearable. Joan makes a list and goes to the store; I tag along. 
Once the groceries are bought, paid for, and loaded into the van, we head back. Once we get back, Joan calls Bob outside to show him that the van is overheating. Bob's first question is "What did you do to it?" Joan insists she did nothing, saying everything was fine until we got almost home. She looks at me to confirm her story and I do. Bob looks at it and decides that it will just have to go to a mechanic in the morning. The groceries get unloaded and we all go inside.

Joan puts away the groceries and Bob once again begins to ask about lunch. Finally, it is put in front of him and he is happy, watching football, drinking beer, and eating his lunch. He makes a few more "jokes" about AfricanAmerican football players.

The afternoon wears on and Joan suggests that we go sit on the patio as it would be cooler outside by now. We go outside and soon Bob turns the discussion to dinner. Joan tells him that she will barbecue tonight and he says he'll help her--he will light the grill and she can cook.

Bob starts the grill and Joan goes inside to start preparing the meat and some pasta salad. Unfortunately for Joan, she doesn't get the meat ready fast enough for Bob because he soon appears in the kitchen saying, "I guess I started the grill for nothing, honey." Awhile later, he comes back and criticizes Joan for cooking too much pasta. I ask Bob if he has ever cooked and both Joan and Bob laugh. Bob responds, "I think I cooked once."

Bob goes back outside and Joan and I talk while we cook. Joan tells me that she had been working three jobs (one "under the table"), 90 hours a week at 
one point but she had to stop because the stress was so great. She had been cooking meals in the morning before going to work so the rest of the family could just heat it up later. She would call and help her children with their homework over the phone. She did the cleaning when she could--even while working all those hours, she had the total responsibility for care of the home. On this particular night, I do the dishes and then we all go to bed; I sleep on the sleep sofa in the living room.

The next morning is Monday and things begin early. The dog must be given special medicine to help with the many allergies he has. He barks and everyone bustles about. Joan drives Nancy to school; Bob follows a short time later with Michelle. Suddenly the house is quiet again. I cannot go back to sleep so I decide to get up and have some coffee. Afterwards I shower and dress. Suddenly the phone rings, it is Bob asking me to pick up Michelle at school as she is sick. I do this.

Later, I find out that this is a common problem. Michelle does not want to go to school, so she often goes to see the school nurse to complain that she is not feeling well. Often, she is warm and the school will send her home. One day the school sent her home with a "temperature" of $99^{\circ}$.

Another common scenario occurred the following day. Bob was to take her to school. They were set to leave when Michelle went into the bathroom and got sick. Bob tells her she can stay home from school and calls the school to excuse her. When he tells Joan what has happened, he asks her, "What did you 
say to her?" Joan spends much time wondering what she did wrong and how she can fix it. One morning we stand in the kitchen with her sobbing on my shoulder, crying "What can I do?" I assure her that she is a great mother and this isn't her fault. Joan wants to go to talk to the school counselor about this problem and she wants Bob to go too. Bob seems a bit reluctant to go and Joan spends a lot of time rationalizing her desire for him to go.

Joan feels guilty because she has a job outside the home. She works as a home health aide, caring for elderly people. When she talks about her job she talks about the fact that the family would not be able to make it without her income. The next thing she says is that her clients need her. Finally, almost as an afterthought, she says "And I like my job and I'm good at it."

Nancy is 16 years old. She has a drivers license and drives the family van. This has caused their insurance premium to go up several hundred dollars a year. Joan and Bob pay for this. At first, Nancy was somewhat resistant to the idea of getting a job, but she decided to apply at a few places. Her first choice was to work in "The Gap"--a clothing store located in a shopping mall. She did not want to work (nor did she want her mother to work) at a place like McDonalds because she felt it would be embarrassing if her friends found out. Apparently, some of Nancy's friends live in families that are more financially secure than the Peters'; and Joan feels pressure to make sure that Nancy is not embarrassed or upset by this. Nancy did end up getting a job in a nursing home serving meals and beverages to elderly people on weekends. 
There is a gap of about 5 years between Nancy and Michelle and their lives have been different. When Nancy was a small child, Joan was a "stay-athome mom." Although the family struggled financially, Joan's mother lived nearby and Joan had friends in the area. Joan was also at home for the first few years of Michelle's life. When Michelle started school, Joan got a paying job. She says she felt wonderful being able to contribute to the family. A short time later, the family moved across the country, leaving Joan with no support system. So, while Bob was able to get a job and meet people and the kids were able to go to school and meet people, Joan (who had decided to stay home to help the kids adjust) was isolated in their apartment; according to Joan. After about a year it became clear that they would not be able to make it on Bob's income, so Joan found a job. Joan's mother began to criticize her for not staying home with the kids, saying that she was not as good a mother to Michelle as she was to Nancy because she is no longer staying home. Michelle told me that she has even overheard this.

In spite of the fact that they are older and Joan now works many hours outside the home, the children do not appear to help her with the housework that much. As discussed earlier, when Joan was working three jobs, she did the cooking--even though others in the family are capable of doing it. Nancy sometimes chooses to make herself a salad rather than eating what everyone else eats, but she does not offer to make anything for anyone "ise. Laundry is done by Joan; the laundry she was doing when I arrived hung out on the line for three 
days until I folded it and put in a laundry basket, where it sat on a chair for another day until Joan got around to putting everyone's laundry away.

Joan told me that the cockatiel was originally a gift for Nancy because she begged for one. Now, Nancy has lost interest and it is Joan who must care for the bird. Joan cares for all of the animals. The dog is the most difficult to take care of. He is allergic to many things including human dander. Joan explained that the dog has had many visits to a veterinarian specializing in allergies. The dog was given expensive medication and a special diet. At the time I was there, the dog was supposed to eat nothing but venison and potatoes! According to Joan, this was a big improvement because previously his diet had consisted of nothing but lamb and rice. This had to be cooked fresh daily because lamb and rice based dog food contains other ingredients. Of course, the responsibility for cooking the dog's meals fell to Joan. Joan is nauseated by the smell of lamb, so this was quite an ordeal for her. As she was telling me about this, she was saying, "I must have done something really bad for God to punish me like this."

Joan talks a lot about wishing she could have some time to herself to relax and read a mystery novel. She has been told by a doctor that she needs to take time for herself, to relax, but Joan wonders where she can find the time to do this. She realizes that she is suffering from extreme stress because she tells me about the time she was driving down the road when she became dizzy and felt that she couldn't breathe. as she puts it "I thought, 'Oh my God, I'm having a heart attack' I almost panicked. I thought, 'what am I going to do?' So I got the van to the 
side of the road and sat there 'til it went away." She went to a doctor who told her it was stress causing the problem. She says this has happened a couple more times, although not as severely as the first time.

Joan talks about the family's yearly camping trip as something she looks forward to. It is usually the only vacation the family takes during the year. Joan described the things she does to prepare for this trip. Menus have to be planned and food must be purchased. Tents, food, supplies, must all be packed and then unpacked again at the campsite. While there, cooking and cleaning up must be done. Joan tells me that the last time they went, Bob complained about the food she cooked, comparing it unfavorably to food his brother had.

Joan finally does seem to relax a little bit on the last night I am there. We have gone out to an Italian restaurant for dinner and Joan has had a couple of beers at home beforehand and a couple with dinner. We are on our way home when Nancy remembers that she needs to stop at the store to buy something for school the next day. We get to the store a few minutes before closing time and Nancy runs in while the rest of us wait in the van. Joan makes a couple of jokes and starts laughing. Bob looks at her and says, "Do you have to be so loud?" Joan stops laughing and is quiet for the rest of the ride home.

Once we get home, we sit in the living room and the dog brings out some of his toys. We play with the dog and suddenly Joan says, "Where's kitty?" to the dog. The dog begins to bark and runs around trying to find the cat (who is safe because he spends most of his time locked in the girls' room). Bob begins to 
shout at Joan, "What did you do that for? How stupid." Joan says she just thought it would be funny. Bob tells her that it wasn't funny, it was just stupid. Everyone seems uncomfortable now, so we all go to bed.

The next morning, as I prepare to leave, Joan gives me a hug, says thank you, and begins to cry. I hold her for awhile and tell her it will be alright. It strikes me that I have been something of a support system for her over these past few days and when I leave she will be without support once again. Her extended family lives across the country and, as Joan puts it "When the phone rings, it's never for me, unless it's work." She has no close friends in the area.

And so I take my leave. I admit to feeling somewhat relieved as I left. This was a very painful experience. 


\section{CHAPTER IV}

\section{CONCLUSIONS}

\section{CASE STUDIES: DESCRIPTIVE SUMMARY}

These two case studies both show a tremendous amount of struggle. Sandra struggles against the ideology of motherhood, even though she does not feel completely successful in this struggle. She still feels guilt even though she knows intellectually that she has nothing to feel guilty about. There is sometimes some tension between Sandra and Brian because Sandra is struggling to fulfill some of her own needs. Occasionally, Sandra does put her own needs first instead of catering to everyone else's needs. This seems to make Brian uncomfortable at times, so he tries to get control back by getting upset about something like soda. He seems to be more accepting of Sandra's plans to continue in school than he used to be and so in some ways, Sandra's struggle is successful. She continues to struggle unsuccessfully against fear and guilt, however.

In the case of Joan, we see a woman who struggles simply to make it from one day to the next. Here is a woman who has the total responsibility for caring for virtually everyone around her--her children, her husband, her pets, and her clients. No one takes care of Joan, not even Joan herself. Her entire life consists 
of caring for others. Her job is done in individual homes, so it serves to isolate her further. She has no close friends and, in fact, doesn't seem to have much time to cultivate friendships. She and Bob do not seem to communicate very much, and in any case, far from providing support, Bob is much of the problem. He repeatedly criticizes her, blames her and generally treats her with great disrespect. Joan feels guilty no matter what she does. She feels guilty for working and justifies this by pointing out the financial contribution to the family. However, when she quit two of her jobs and was at home more, she felt guilty about the loss of income. In any case, no matter how many hours Joan works outside the home, she is still responsible for virtually all of the work inside the home. In the end, she will get criticized for the things she does inside the home no matter how much she does.

What theoretical or analytical frameworks can help us understand how the ideology of motherhood can become so deeply ingrained in women (and men) as in the two families studied that their lives can be so severely disrupted by it? I will utilize Michel Foucault's theory about discipline and disciplinary practices and Antonio Gramsci's theory of hegemony to explore this phenomenon. The ideology of motherhood can be seen as an example of what Michel Foucault (1984) calls "disciplinary practices." Foucault describes "discipline" in the following way:

'Discipline'...is a type of power, a modality for its exercise, comprising a whole set of instruments, techniques, procedures, levels of application, targets; it is a 'physics' of an 'anatomy' of power, a technology. And it may be taken over either by 'specialized' 
institutions (the penitentiaries or 'houses of correction' of the nineteenth century), or by institutions that use it as an essential instrument for a particular end (schools, hospitals), or by preexisting authorities that find in it a means of reinforcing or reorganizing their internal mechanisms of power (one day we should show how intrafamilial relations, essentially in the parents-children cell, have become 'disciplined', absorbing since the classical age external schemata, first educational and military, then medical, psychiatric, psychological, which have made the family the privileged locus of emergence for the disciplinary question of the normal and the abnormal), or by apparatuses that have made discipline their principle of internal functioning (the disciplinarization of the administrative apparatus from the Napoleonic period), or finally by state apparatuses whose major, if not exclusive, function is to assure that discipline reigns over society as a whole (the police). (1984:206)

This is not to say that these disciplinary practices are enforced only by societal institutions. As Sandra Lee Bartky argues, these disciplinary practices are enforced by "everyone and no one in particular" (1988:80). In fact, even the mothers themselves engage in what Foucault calls "self surveillance." That is, they have internalized the expectations placed on her and they police themselves and try to act appropriately.

Foucault uses Jeremy Bentham's idea of the Panopticon to illustrate how self-surveillance works. The Panopticon is a prototype for a prison in which there are cells, each meant to hold an individual prisoner. These cells surround a central viewing area in which there is a guard. There is an opening in each cell through which the guard can see the prisoner, but the prisoner cannot see the guard. Thus, the prisoner never knows when he is being watched. He must always assume that he is being watched and he begins to act accordingly. A mother can be said to be under the same type of scrutiny as the prisoner in the 
Panopticon. She knows there is an ideal she is expected to live up to.

Everywhere she turns, she is faced with the ideology. It comes not only from societal institutions such as mass media, education, and family, but from people she does not even know and finally, even from inside herself.

This can be seen in the case of both mothers described earlier. Sandra began her life as a mother with a need to do everything better than her mother had done. She put a great deal of pressure on herself to be the mother she never had as a child in order to give her children the happy childhood she wanted but never got. Sandra goes to great lengths to do everything she believes she is supposed to do. If her house is messy, it bothers her because it will reflect on her children when they have friends over. In spite of the difficulties it causes in terms of time, Sandra does not tell her children they cannot do this or that; she simply puts aside her own needs to make sure they get to practice or to a friend's house. When Brian has business people in town, Sandra must entertain them or go out and socialize with them. Both see it as her responsibility to do so. However, if there is a social occasion that Sandra must attend for school, Brian may or may not be there. So, Sandra puts her own needs last in order to make sure everyone else's needs are met. This is why she often gets up at 3 a.m. to do homework. It is the only time she can be at home and know she will not be disturbed by other members of the family.

Sandra has always felt that it was her responsibility to help Shawna as much as possible to succeed in school. This has been a formidable task. Because 
of the nature of Shawna's learning difficulties, Sandra has had to help her with homework for a great deal of time each day. Sandra has told me that Shawna has two to three hours of homework virtually every day since second grade. For Sandra, there was never any question but that this was her responsibility. Brian has not had to deal with this for the most part. Now that Sandra is in school, however, it has been a struggle for her to get the rest of the family to see her going to school as anything other than a hobby. In fact, it has been fairly recently that Sandra herself has seen school as a very important part of her life. It has been the one thing that has been given up when things got to be too much for Sandra. When Sandra's mother became ill, she took a year off. When children's activities were in conflict with a particular class, Sandra simply did not take that particular class. Even now, homework gets done in the middle of the night so that all of Sandra's other responsibilities can be met.

Focault's idea of self-surveillance can also be seen very clearly in the case of Joan. Joan has been told over and over again by her mother and by her husband that the care for everyone in the family is her responsibility. She now believes this. She does not ask for help with the housework from Bob or the kids. Even when she was working ninety hours a week she continued to do all of the housework. She is responsible for seeing that Michelle gets to school and for helping Michelle get her homework done--Bob is simply not expected to do anything. Michelle's problems are blamed on Joan, and she has internalized this, asking "What have I done to cause this?" Or "What can I do to fix this?" No one 
considers requiring Bob to do anything. Bob is able to come home from work and, with a clear conscience, take a shower, put on clean clothes, eat a dinner that has been fully prepared for him, have his mess cleaned up by someone else, sit down in a clean home and watch television or play computer games. Once he comes home from work, there is no idea on his part that he should do anything else. It does not occur to anyone else that he should do otherwise. By the same token, it would not occur to Joan (or anyone else) that she could do anything else but come home from work, make dinner, do the dishes, do laundry, help with homework for as long as it takes, and fall into bed, exhausted. These expectations are placed on her by everyone around her and by herself, as well.

How tight are the bonds of ideology in the case of these two mothers? Antonio Gramsci's concept of cultural hegemony is useful in looking at how much room mothers have to maneuver within the ideology of motherhood. Raymond Williams describes how cultural hegemony works in the following way:

Hegemony is then not only the articulate upper level of 'ideology', nor are its forms of control only those seen as 'manipulation' or 'indoctrination'. It is a whole body of practices and expectations over the whole of living: our senses and assignments of energy, our shaping perceptions of ourselves and our world. It is a lived system of meanings and values--constitutive and constituting--which as they are experienced as practices appear as reciprocally confirming. It thus constitutes a sense of reality for most people in the society, a sense of absolute because experienced reality beyond which it is very difficult for most members of society to move, in most areas of their lives. It that is to say, in the strongest sense a 'culture' but a culture which has also to be seen as the lived dominance and subordination of particular classes (1977:110).

The ideology of motherhood is a fine example of this. As stated earlier, 
mothering is seen as something that comes naturally to women. The rules and ideas about what makes a "good mother" are so ingrained in us that it simply seems that it is "just the way things are." It is only when we look at how ideas about what a "good mother" is have changed over time that we can begin to see that motherhood is a cultural construct. It is easy to imagine what would happen to a woman in this culture who decided not to be a mother or who decided to be a different kind of mother than the ideology allows. What would happen if Sandra and Joan decided that they were not solely responsible for seeing that their children did well in school? Both mothers have a daughter who has difficulty in school and both put in a great deal of time helping these children succeed. What if both demanded that their husbands and/or the schools take up some of the slack? I would argue that they would be labeled "irresponsible mothers." The fathers would get positive feedback if they decided to help, or no negative feedback if they did nothing. What if both mothers decided to "share" responsibility for housework with the other members of the family? Again, people would have sympathy for the families and the mothers would be seen as shirking their responsibilities. Again, the point here is that while both Sandra and Joan have pressure put on them from media, educational system, politicians-talking about "traditional family values" and "parental" responsibility, they also are products of their culture. They believe in the ideology of motherhood themselves, even if to different degrees. They feel the pressure to do a good job and the guilt from feeling as if they are not doing a good job and somehow their children are 
paying for it. This is the power of cultural hegemony--it makes these ideologies seem natural and correct. In fact, as T. J. Jackson Lears puts it:

The available vocabulary helps mark the boundaries of permissible discourse, discourages the clarification of social alternatives, and makes it difficult for the dispossessed to locate the source of their unease, let alone remedy it (1985: 569-70).

This is not to say that every mother completely falls victim to the ideology. In looking at hegemony, it is generally conceded that "... some are more socialized than others" (Lears 1985:570). This can clearly be seen in the case of Sandra. As her husband changed jobs so he was home more and her children got older, Sandra was able to shift her relationship to the ideology. As she began to go to school and get more confidence in herself, she was able to begin to stand up for what she needed in the family. Of course, she was not completely successful in this challenge to the ideology (as I argue no one is). This is part of how cultural hegemony works. People may try to resist the norms of the culture, "but normally most people find it difficult, if not impossible, to translate the outlook implicit in their experience into a conception of the world that will directly challenge the hegemonic culture" (Lears 1985:569).

It is clear from these two case studies that guilt plays a large role in keeping the ideology in place. By making mothers responsible for how their children turn out, society has a convenient scapegoat. This allows the status quo to continue. By blaming mothers, society escapes responsibility for providing prenatal care, school lunches, and after school activities for children and youth to participate in while their parents are at work. That is not to say that no child gets 
these things, but that society feels no responsibility to provide them.

By making mothers responsible, employers have a reason to hold women back from promotions. The argument is that women will take more days off to care for their children than men will. It is women who get called at work to deal with a sick child or a school problem. Women feel very torn between their responsibilities to their jobs and their responsibilities toward their children.

In talking to mothers in general, it is clear that when fathers are involved with their children, in however small a capacity, they get a great deal of credit. If a father goes to a meeting with a child's teacher, for example, he will be seen as "going the extra mile" for his child. If a mother goes, she is simply doing what's expected of her.

The ideology works because it tells mothers that their children will pay the price for their inadequacy. Of course most mothers, if asked, would say that they wanted their children to lead happy, productive lives, and most mothers want to do what is best for their children. Unfortunately, when there are "experts" telling mothers what they should be doing, and this advice is impossible to live up to, mothers never feel like the job they are doing is good enough. The ideology of motherhood sets up such unrealistic expectations that all mothers will fail to one degree or another to live up to these expectations and the guilt continues. In looking at this phenomenon, there is an emphasis on day-to-day routines of life and the implications involved for the people involved and for the system itself. As stated earlier, the guilt involved in the ideology allows the status quo to 
continue. By internalizing the guilt and the expectations placed upon them, mothers help to reproduce the very ideology that oppresses them. But what is the alternative?

As we have seen, Sandra is aware of the ideology. She struggles against it, but it is a part of her culture as she herself is. There is no way to completely escape the effects of the ideology on her life. As Ortner points out, "There is actually a profound philosophic issue here: how, if actors are fully cultural beings, they could ever do anything that does not in some way carry forward core cultural assumptions" (1994:398). The best that can be hoped for is that some women will have some of the guilt and responsibility relieved as they demand that others share in the responsibility for raising children. As we have seen with Sandra, however, awareness does not in and of itself lead to an easing of the burden.

People in the United States have always seen individualism as a virtue and indeed the culture is built upon this idea. This is part of the reason why the ideology of motherhood has been able to evolve as it did. By making individual mothers responsible for everything that happens to their children, society does not have to bear any responsibility for the children. Mothers serve as a convenient scapegoat to shoulder the blame for "the ills of society." Women are paying a heavy price for this. As we have seen in the lives of Sandra and Joan, this ideology causes women a great deal of emotional and sometimes physical pain. Until others begin to share in the responsibility of raising children to independence, mothers will continue to pay the price by sacrificing a large part of 
themselves and their lives on the altar of motherhood. 


\section{REFERENCES}

Bartky, Sandra Lee

1988 Foucault, Femininity and the Modernization of Patriarchal Power. In

Feminism and Foucault: Reflections on Resistance. Irene Diamond and

Lee Quinby, eds. Pp 61-86. Boston: Northeastern University Press

Berry, Mary Francis

1993 The Politics of Parenthood: Child Care, Women's Rights and the Myth of the Good Mother. N.Y.:Viking

Code, Lorraine

1991 What Can She Know? Feminist Theory and the Construction of Knowledge. Ithaca and London: Cornell University Press

Coontz, Stephanie

1992 The Way We Never Were: American Families and the Nostalgia

Trap. N.Y.: Basic Books

Ehrenreich, Barbara and Deirdre English

1978 For Her Own Good: 150 Years of the Experts Advice to Women. Garden City, N.Y.: Anchor Press

Farganis, Sondra

1986 Social Reconstruction of the Feminine Character. Totowa, J.Jm:

Rowman and Littlefield

Glenn, Evelyn Nakano

1994 Social Constructions of Mothering: A Thematic Overview. in Mothering: Ideology, Experience and Agency. Evelyn Nakano Glenn, Grace Chang and Linda Rennie, eds. Pp 1-29. London and N.Y.:

Routledge

Gordon, Tuula

1990 Feminist Mothers. N.Y.: N.Y. University Press

Hochschild, Arlie with Anne Machung

1989 The Second Shift: Working Parents and the Revolution at Home.

N.Y.: Viking 
Lears, T.J. Jackson

1985 The Concept of Cultural Hegemony: Problems and Possibilities.

American Historical Review 90 (3):567-593

Llewelyn Sue and Kate Osborne

1990 Women's Lives. London and N.Y.: Routledge

Mackinnon, Catharine

1989 Toward a Feminist Theory of the State. Cambridge, MA and

London: Harvard University Press

Margolis, Maxine L.

1984 Mothers and Such: Views of American Women and Why They

Changed. Berkeley, CA: University of California Press

Mintz, Steven and Susan Kellogg

1988 Domestic Revolutions: A Social History of American Family Life.

N.Y.: The Free Press

Ortner, Sherry

1994 [1984] Theory in Anthropology Since the Sixties. In

Culture/Power/History: A Reader in Contemporary Social Theory.

Nicholas B. Dirks, Geoff Eley, and Sherry Ortner, eds. Pp 155-199.

Princeton, N.J.: Princeton University Press

Radl, Shirley Rogers

1987 Mother's Day is Over: The Realities and Rewards of Motherhood

Today, N.Y.: Arbor House

Rapp, Rayna

1992 Family and Class in Contemporary America: Notes Toward an Understanding of Ideology. In Rethinking the Family: Some Feminist

Questions. Barrie Thorne and Marilyn Yalom, eds. Pp 49-70. Boston:

Northeastern University Press

Rich, Adrienne

1976 Of Woman Born: Motherhood as Experience and Institution. N.Y.:

Bantam Books

Rossiter, Amy

1988 From Private to Public: A Feminist Exploration of Early Mothering.

Toronto: The Woman's Press 
Rothman, Barbara Katz

1994 Beyond Mothers and Fathers: Ideology in a Patriarchal Society. In Mothering: Ideology, Experience and Agency. Evelyn Nakano Glenn, Grace Chang and Linda Rennie Forcey, eds. Pp 139-157. N.Y. and London: Routledge

Scheper-Hughes, Nancy

1994 Mothers Love: Death Without Weeping. In Conformity and Conflict: Readings in Cultural Anthropology. James P. Spradley and David W.

McCurdy, eds. Pp. 201-210. N.Y.: Harper Collins

Schwartz, Judith D.

1993 The Mother Puzzle: A New Generation Reckons With Motherhood.

N.Y.: Simon Schuster

Skolnick, Arlene

1991 Embattled Paradise: The American Family in an Age of Uncertainty.

N.Y.: Basic Books

Stacey, Judith

1990 Brave New Families: Stories of Domestic Upheaval in Late Twentieth Century America. N.Y.: Basic Books

Thorne, Barrie

1992 Feminism and the Family: Two Decades of Thought. In Rethinking the Family: Some Feminist Questions. Barrie Thorne and Marilyn Yalom, eds. Pp 3-30. Boston: Northeastern University Press

Walters, Suzanna Danita

1992 Lives Together/Worlds Apart: Mothers and Daughters in Popular

Culture. Berkeley, CA: University of California Press

Wearing, Betsy

1984 The Ideology of Motherhood: A Study of Sydney Suburban Mothers.

Sydney: George Allen and Unwin

Williams, Raymond

1977 Hegemony. In Marxism and Literature. Pp 108-114 Oxford: Oxford University Press 
Wolf, Margery

1994 Uterine Families and the Women's Community. In Conformity and Conflict: Readings in Cultural Anthropology. James P. Spradley and David W. McCurdy, eds. Pp. 229-235 N.Y.: Harper Collins -1992 A Thrice-Told Tale: Feminism, Postmodernism and Ethnographic Responsibility. Stanford, CA: Stanford University Press

Yin, Robert K.

1984 Case Study Research. Beverly Hills, CA: Sage Publications 